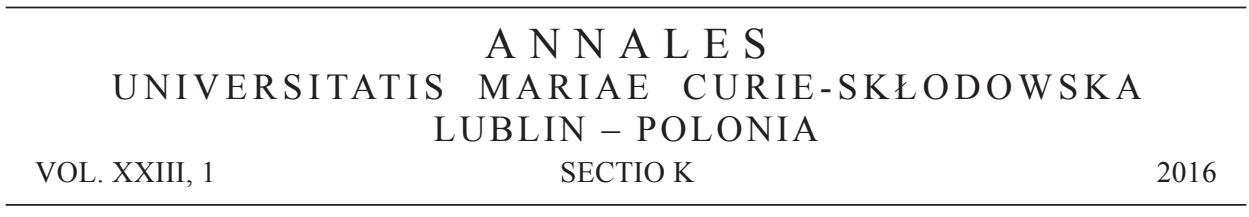

Faculty of Political Science, University of Maria Curie-Skłodowska in Lublin, Poland

\title{
Changes and Challenges: Local Representative Democracy in Poland ${ }^{1}$
}

\begin{abstract}
The purpose of this paper is to report on how elected representatives perceive the current status and role of municipal council in governing process. The particular attention is paid to the impact of the introduced in 2002 leadership reform and influence of new participatory framework on council's position and say. The paper draws on empirical data collected in municipalities of the Lubelskie region under two, separate research projects in 2015 and 2016. The main research findings indicate that representing residents' interests and controlling the executive constitute the priorities for Polish councillors. Local representatives think, at the same time, that their role in governing process constantly diminishes. The main impact on this situation had the introduction of elected mayors which not only limited council's say but also changed the governing pattern.
\end{abstract}

Key words: municipality, representative democracy, councillor, Poland

\section{INTRODUCTION}

Since the turn of $18^{\text {th }}$ and $19^{\text {th }}$ century, when democratically elected self-government was established, in a number of Western European countries local democracy underwent major transformation. Changes included both the values upon which local institutions are built, and thus the understanding of the idea of self-governing, the

1 The article presents the partial outcomes of twoscientific projects, a) Mobility Plus funded by Polish Ministry of Science and Higher Education (No. 110/MOB/2013/0) and b) the National Science Centre (Poland) (No. 2013/09/B/HS5/04403). The earlier version of the article was presented during the $24^{\text {th }}$ Annual NISPAcee Conference organised on 19-21 May 2016 in Zagreb, Croatia. 
optimal size and scope of tasks of local units as well as organization of their bodies. Additionally, the turn of the $21^{\text {st }}$ century brought progressive reforms connected with globalization, Europeanization, and urbanization of local governments, as well as some other meso and micro trends such as need for more citizen-oriented governing [Denters, Rose 2005: 5-6].

In Central and Eastern European countries (CEE) that still relatively recently underwent political transformation, and introduced many reforms not in decades but rather years the above-mentioned changes have taken perhaps even more intensive form [Campbell, Coulson 2006]. In Poland, the first wave of decentralisation reforms was implemented in the 1990s. On their ground municipality (gmina) became the basic, but also the most vital, local unit. The second wave of decentralisation, namely the introduction of counties (powiaty) and the change in number and status of regions (województwa), conducted in 1998, did not change the situation. ${ }^{2}$ Moreover, due to the increase in the number of own tasks, the role of municipalities in overall structure of Polish local self-government was even strengthened. ${ }^{3}$ Presently, almost 2,500 municipalities are responsible inter alia for provision of selected municipal and social services, local spatial planning, environmental protection, local roads, local culture, communal housing and education at pre-school and primary levels.

The governing process at the municipal level is based in Poland on representative democracy [Pitkin 1969; Manin 1997]. The municipal council, collective body that not only represents citizens' interests but also makes binding decisions plays the key role here. However, it seems that trends and reforms introduced to Polish municipal government especially during last 15 years, in particular the change of leadership model and shift to more participative governance, resulted in a decline of council's actual if not the formal position. Therefore, the purpose of this article is to examine current status and role of elected councils in municipal governance, perceived by councillors. In particular, the article looks for the answers to the following research questions:

- How do councillors perceive council's role? How/if the role has evolved in their opinion since 1990 ?

- How do councillors perceive scope of council's say in shaping local environment in relation to other local bodies?

- What is councillors' attitude to the reforms implemented at the local level, in particular those aiming at strengthening mayoral leadership and citizens' engagement into decision-making process?

The article is mainly based on the outcomes of qualitative research conducted among councillors form selected municipalities in the Lubelskie region. Additionally, the article refers to councillors' observations and comments, collected during

\footnotetext{
2 The reform entered into force on 1 January 1999.

3 According to the first Local Government Act, municipalities had 15 own tasks. Since then the number was increased to 22 .
} 
in-depth interviews with them. The paper starts (Section 2) with the brief analysis of the trends and factors that both shape and challenge representative democracy at the local level. Section 3 focuses directly on Poland, and extensively examines legal and institutional framework municipal councils operate in. Section 4 elaborates on methodology of the research in a more detail way. The next section presents main research findings. Finally, the conclusions and discussion close the paper.

\section{REPRESENTATIVE DEMOCRACY IN THE CHANGING CONTEXT OF LOCAL SELF- GOVERNMENT}

The classical model of representative democracy is based on the division of labour between citizens and elected representatives [Pitkin 1969]. In this model, the elected officials, acting on behalf of the citizens and organised in the representative body, are the highest decision makers in the system and supervise the performance of the executive branch [Daemen 2012]. Through the centuries that model operated in Western democracies at the national level, afterwards being successfully transferred to the local one. Nevertheless, since then local democracy has changed a lot, in most of the countries municipal councils are still perceived as main representative bodies and a core institution of liberal democracy [Heinelt 2013: 641].

Local councils are collective bodies that play various roles. First and foremost they represent interest of communities. Second, what is directly linked with the previous issue, they translate citizens' needs and demands into binding decisions. Third, the councils shape local policies, and fourth, they scrutinize the executive body. Finally, in some especially Western and Nordic democracies, municipal councils have important political role, as the majority of councillors are party members, who are supposed to represent the interests of their party formation at the local level. Beyond this simple typology, it should be argued nevertheless that the actual performance of the roles by the councils in particular country is shaped both by the accepted notion of local democracy, adopted model of local self-government as well as formal and informal institutional structures [Heinelt 2013; Radzik-Maruszak 2014].

However, through many decades, elected local councils have constituted the heart and essence of local democracy, the trends and reforms implemented in self-government particularly during the last thirty years resulted in a decline of their actual, if not the formal, position. Therefore, in many countries the councils are not considered any more as the primary channel through which citizens' needs and demands are passed for the communication and control of key local political decisions [Denters, Klok 2012] but rather are one of the many local institutions. The change resulted from several issues.

First, in the 1970s and the 1980s, local representative democracy was influenced by market-oriented reforms. The paradigm of New Public Management not only introduced to public sector solutions and practices taken from private one, but also 
influenced the values public administration operated on. The emphasis was put on economy, efficiency, and effectiveness that often resulted in reinforcement of professional administrators over elected politicians. The latter ones, 'relieved' from making complicated decisions, were supposed to focus on establishing broader, more general objectives and frameworks [Nyhom, Haveri 2009: 111]. The paradigm had significant implications for elected representatives especially in the Anglo-Saxon and Nordic countries where the interest in the paradigm was the highest. Second, the 1990s brought attention to the shift from government to governance, meaning, as Hansen indicates, the "shift from traditional, representative and hierarchical forms of state governance towards new, horizontal and network-oriented forms that transgress and blur traditional demarcations between what is public versus private, political versus administrative, and between governors versus governed" [Hansen 2001:219]. At the local level, the consequences of the change were at least twofold. On the one hand, many countries decided to replace collective, local executives by directly elected mayors, perceived as true, visible leaders who are able to cope with governance challenges. The solution was adopted inter alia in Italy, England ${ }^{4}$ but also in some Central and Eastern European countries such as Poland, Slovakia or Croatia [Berg, Rao 2005; Denters, Rose 2005; Bäck, Heinelt, Magnier 2006]. In many cases, the new intuitional framework implied that the council no longer was able to claim political primacy based on its democratic legitimacy as being the only directly elected local political office [Denters, Klok 2012]. On the other hand, the status and legitimacy of the council was hollowed out by the new, more direct forms of citizens' engagement into governing process. At first, many countries have decided to strengthen the role of local consultations and referenda, then to complete existing institutional framework by new solutions such as local initiative or participatory budgeting.

Finally, referring to the factors affecting the council's status and roles, other general tendencies (globalisation, Europeanization, urbanisation) as well as meso and micro trends should not be ignored. Firstly, in many countries there has been a marked decline in the level of trust in local institutions, including political parties and groupings, which have a vital role to play in a representative democracy. Secondly, citizens became not only better educated but also more critical towards national and local authorities, which often leads them to take initiative to solve problems on their own. This is reflected not only in the so-called grassroots governance movements, but also in ideas such as co-creation and co-production of local services. The latter one visibly changes governance arrangements and working culture of local governments [Tuurnas 2015]. Thirdly, in a view of the economic crisis and financial austerity, a number of countries decided to implement structural-functional reforms. Some countries have acted to reduce the number of municipalities (the Netherlands, Denmark, Finland), whereas others have opted to change the powers of local government (Finland) [Radzik-Maruszak 2016].

\footnotetext{
4 Only in some units. Currently, (September 2016), there are 17 directly elected mayors in England.
} 


\section{LEGAL AND INSTITUTIONAL ARRANGEMENTS OF COUNCILS' OPERATION AND DEVELOPMENTS IN POLISH MUNICIPAL GOVERNANCE}

Poland is presently (September 2016) divided into 2,478 municipalities having different rural, urban or mixed status. In each municipality the power is divided between the council and the mayor. The powers of the council include all matters that are not entrusted by law to other bodies. The council is understood mainly as the representative and the highest decision-making body. Interestingly, on the background of other European countries, the Polish municipal councils have, at least in theory, limited political role, as parties are presented only in some, rather big, municipalities.

Since the democratic transformation in 1990, the legal and institutional environment municipal councils operate in has evolved a lot, which has affected the status of the body. Between 1990 and 2002, the position and role of municipal councils were relatively high. The council consisted of 15 to 100 councillors, was elected in popular and direct voting for a four-year term. Importantly, the body not only played representative and decision-making roles but also had a significant say in creation of executive power. The executive board, consisting of the mayor, her/his deputies and other members (4 to 7 persons) was selected either from councillors or from those outside the council. Interestingly, in the former situation, the board members did not lose their councillors' mandates and were able to vote during council's meetings. The council had a right to recall the board before the end of term. Initially, the procedure was relatively easy to carry out, ${ }^{5}$ but gradually, the conditions of the recall were tightened. That rather strong status of the council was additionally reinforced by the presence of the cumul des mandats rule. The possibility of combining the mandate of councillor with the parliamentary seat was, however, abolished soon. The solution that successfully operates in many countries, including France and Finland, proved to be too challenging for young, developing democracy.

In the history of municipal representative democracy, the year 2002 constitutes the turning point as two major institutional reforms were implemented then. First, the number of councillors was significantly reduced. Nevertheless, the reform was introduced at all three levels of local self-government (municipal, county and regional) the change was particularly noticeable in large municipalities. In cities with 250,000 inhabitants, the number of elected representatives was limited from 50 to 28. As Swianiewicz indicates, the reform was an outcome of populist discourse about 'cheap state' and expensive and not productive representatives [Swianiewicz 2012: 493]. Second, Poland decided to alter local leadership model and replace the collegiate, selected by the council board, by the directly elected mayor. The change reflected the trends presented at that time in other European countries [see: Berg, Rao 2005]. In case of Poland, having chosen such a solution, most of all an increase in the activeness of local elections and improvement of effectiveness of municipal

\footnotetext{
5 The absolute majority of votes of council members.
} 
management were expected. However, already in the beginning, opponents of the reform indicated possible problems, inter alia tensions between the council and the mayor resulted of their different political affiliation [Radzik-Maruszak 2014].

Since 2002, the power in all municipalities is held by the council and the mayor. The council consists of 15 to 45 members, and is elected in universal, equal, direct and secret voting for a four-year term. As mentioned before, the body has a right to decide on all municipal matters unless the law provides other regulations. In particular, the council is responsible for adoption of municipal statute, budget and passing local resolutions and laws. It also decides on mayor's salary, determines her/his activities and accepts reports regarding the latter ones. Additionally, through the audit committee, the council supervises activity of the mayor, municipal organizational units and other sub-municipal units such as villages, districts, and neighbourhoods. The council elects the chair and from 1 to 3 vice-chairs. The chair is responsible for organising council's meetings and preparing its agenda. The meetings are called at least once in four months.

The mayor deals with current affairs and represents municipality. She/he is also responsible for preparing draft resolutions and programs of municipal development. Moreover, the mayor determines the way council resolutions are implemented, proposes and puts into effect municipal budget. Finally, she/he is the head of municipal office, with a right to hire and dismiss municipal officials.

However, to have a complete picture of an environment municipal councils operate in, it is necessary to refer to other trends presented at the local level. In the context of local representative democracy, particularly important seems to be the shift from traditional governing into more (participative) governance [Fischer 2012]. ${ }^{6}$ The trend took two forms. On the one hand, Poland constitutes an example of the country where, through the time, citizens have got many new opportunities of being included into local decision-making process. Presently, they can take part in local elections and referenda, express their opinion in local consultations but are also entitled to use many other tools such as local initiative or participatory budgeting. ${ }^{7}$ Therefore, citizens stopped to be perceived only as voters, and started to be seen as initiators, spiritus movens of local changes and developments or partners in co-governance. On the other hand, through the time, municipal councils have started to be surrounded by other bodies and councils that represent interest of particular groups of citizens. In many municipalities, auxiliary units (villages, districts, neighbourhoods) play an important role. These sub-municipal units not only have their own village gatherings, village heads (in rural municipalities) or directly elected councils (in

6 The operation of Polish self-governments is still largely based on traditionally understood local institutions, and cannot be compared to the environment Anglo-Saxon or Nordic local authorities act within. Referring to governance idea, it is, however, very visible that concept of 'citizens' empowerment' plays more and more important role.

7 Both local initiative and participatory budgeting have, however, voluntary character and municipal council formally has to approve their application. 
urban municipalities) but also limited budgets. Nevertheless, the units still cannot be treated as very important players on local scene [see: Swianiewicz 2014], their presence undoubtedly influences the way municipalities are governed. Additionally, in many municipalities the main council is surrounded by other bodies (councils) that represent interest of NGOs, seniors, youth or other parts of society. In general, the role of these bodies is to give an opinion and advice, however, depending on the municipality, their say is either expanded or narrowed. Finally, the impact of some other trends in representative democracy should not be neglected. Mainly due to a Europeanization process, municipal governing became more complicated, which in many units has strengthened the role of municipal officials.

\section{METHODOLOGY OF THE RESEARCH}

The article draws on research from two separate projects, conducted among councillors sitting on rural, urban and mixed municipal councils. The first survey, conducted between April and May 2015, was a part of the project funded by the Polish Ministry of Science and Higher Education (No. 110/MOB/2013/0), and examined the relationship between municipal council and other municipal bodies, actors and stakeholders engaged in governing process in Poland and Finland. The aim of the research was to study how these relationships and mutual dependencies influence municipal representative democracy and council's say in governing process. In Poland, the questionnaire was distributed among councillors from 21 selected municipalities located in the Lubelskie region $(\mathrm{N}=410) .{ }^{8}$ The biggest municipality the questionnaire was sent to was the city of Lublin (around 341 thousand inhabitants), while the smallest unit was a rural municipality of Terespol (almost 7 thousand inhabitants). Although a digital (e-mail) form of distribution was chosen at first, due to limited returns the survey was re-sent using a traditional, paper format to some municipalities. The final return rate reached $23 \%$ in Poland.

The survey contained 25 questions in total, both closed and open in character. However, the following paper refers only to four of them. First, in order to identify the role of the municipal council, councillors were asked in the survey to order - in terms of importance - the tasks delivered by the council (Q 5). Second, to examine the scope of a council's say within decision-making process, local representatives were asked to order individual subjects/bodies according to the influence they have on the decisions undertaken in the municipality (Q 9). Third, local representatives were asked to determine the impact of various local reforms on the council's operation (Q 7). The importance of tasks and reforms as well as the influence of various subjects was defined by the councillors on a scale of $0-4$, where 0 represented "none", 1 -"small", 2 -"medium", 3 -"large" and 4 -"very large". The weighted average,

\footnotetext{
${ }^{8}$ In the Lubelskie region, there are 213 municipalities in total.
} 
based on the answers given in the survey, meant it was possible to put in order the tasks of the councils, starting with those of the greatest importance to those which have little value and to define the influence of the council on the governing process as well as to measure the impact of different reforms on council's operations. In addition, the survey questionnaire also contained a question relating to the issue of whether the council's role had been changed recently, and if so - how? (Q 6). This question was responded by 71 Polish councillors. Their feedback allowed not only the examination of the changing council's role but also deeper investigation into councilors' attitude to implemented reforms.

The collected quantitative data were complemented by the results of in-depth interviews conducted with councillors form selected local units $(\mathrm{N}=18)$. The interviews were a part of the research project on municipal representatives from four European countries - England, Finland, Poland and Slovenia, financed by the National Science Centre (Poland) (No. 2013/09/B/HS5/04403). In the process of selecting interviewees, their experience (number of terms served as a councillor), status within the council (back or front-row councillor) as well as their party/local committee affiliation were taken into account. During the interviews special themes were discussed though the interviewees were also permitted to talk freely about their personal views. That approach allowed the councillors to share their own interpretations with little steering from the interviewer. The qualitative data was reviewed using a thematic analysis. All interviews were recorded and transcribed.

\section{RESEARCH RESULTS}

The results of the survey suggest that the two most important tasks for local councils are: representing the interests of the residents and controlling the mayor. Subsequently, the list includes defining the financial strategy of the municipality and its budgets, defining the activities undertaken within the municipality and supporting the mayor. Slightly less important are representing specific groups of residents, monitoring the activities undertaken within the municipality, resolving conflicts and deciding about the access to and quality of services on offer. The councillors voted the following as the least important: making it easier for residents to make decisions, coordinating cooperation with other levels of local government and interested parties, as well as introducing the policies of political parties/the election committees (Figure 1).

What does it say about the roles played by municipal councils? First, the above-mentioned results of research indicate that the Polish municipal councils are rather focused "outwardly" in their operations. It seems the councillors consider their priority to be representing the interests important to residents (representative role). A key role to them also involves controlling the executive body (control role). The councillors attach a bit lesser importance to deciding about access and quality of services (decision-making role). Second, above all, in the context of the idea of 


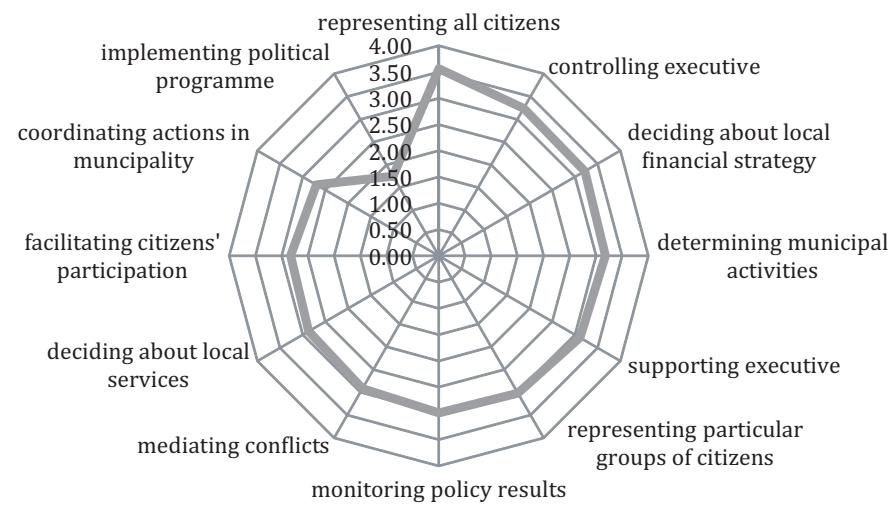

Figure 1. Importance of different tasks as perceived by councillors

Mean value: $0-4$

Source: Own studies.

direct civic participation which is developing in Poland, the councillors do not see making it easier for residents to take part in decision-making processes as a priority. In their opinion, the representative body is not also called up to action programmes initiated by political parties and election committees (political role).

However, the conducted interviews indicate that above this simple typology, local representatives see other council's roles as important. According to them, the body sets priorities and cares of the overall, balanced development of the municipality. One of the councillors' comments on this in the following way: "(...) Each councillor should listen to his/her constituents, then you have to sit in a smaller group, and this is why we have council - to look at the whole municipality and to make some decisions and then to explain them in the constituencies (...) People should see the whole municipality, not only their own backyards (...) so (as a councillor - K.R.-M.) you have to activate, listen to, and then explain to the people why such decisions have been undertaken (...)" (Councillor 2, Bełżyce). The other councillor adds in this context: "(The council's role - K.R.-M.) is to advise, suggest and guide city policy to the right directions (...) the councillor has a direct contact with city residents and should have sense of their needs (...), then you have to set up priorities, and subsequently getthe most important, the most urgent matters done (...)" (Councillor 1, Lublin).

Referring to the second question posed in the article, about the scope of council's say in shaping local environment, it should be noted that according to Polish local representatives the biggest influence on the activities within the municipality have the mayor, than the council and the chair of the council. The CEO, top-level bureaucrats and the chairs of the various councils' committees follow them. The councillors assessed their own influence as average, and interestingly enough lower in the pecking order than low-level bureaucrats. The lowest level of influence was assigned to councillors who had no additional functions within each council (Figure 2). 


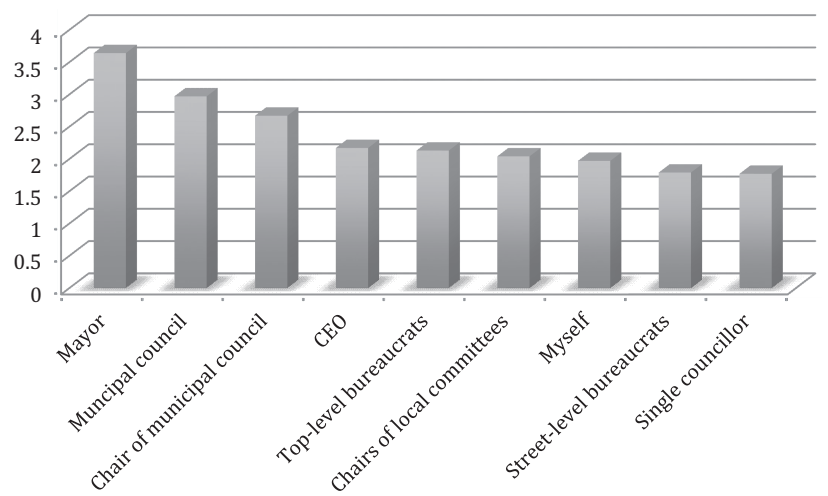

Figure 2. The influence on decisions taken in the municipality as perceived by councillors

Mean value: $0-4$.

Source: Own studies.

From councillors' point of view, the reform that has had the greatest impact on the council's operation was the introduction of directly elected mayors. The role and status of the council has been, however, affected also by solutions aimed at increasing the citizens' participation in decision-making processes such as local consultations, referenda or new forms of civic engagement, including participatory budgeting. The transfer of new powers to an auxiliary unit also constitutes an important role. According to councilors, the introduction of gender quotas on electoral lists, hypothetical division of municipalities and the increase of the number of councillors have had relatively the least impact on the council. ${ }^{9}$

The importance of the introduction of directly elected mayors has been confirmed also in the councillors' comments on the open question as well as during the interviews. On the one hand, some local representatives emphasize that the reform brought irreversible change of balance, meaning the constant strengthening of the mayor's role in a governing process. One of the interviewees addressed to this issue in the following way: "( $\ldots$ ) at the time when the change occurred (2002 - K.R.-M.) I thought it was very good that the mayor had big power and was not so dependent on the council but now I hesitate, these relations (between the council and the mayors - K.R.-M.) have been disturbed, very disturbed. The council has so little influence. Before 2002 it was, say, $50 \%$ to $50 \%$, now it is $90 \%$ for the mayor and $10 \%$ for the council" (Councillor 3, Lublin).

On the other hand, a part of councillors indicate that the council's role has been reduced down to 'little voting machine'. The main initiator of the decision-making process, above all connected with the sphere of finance, happens to be the mayor.

9 In the above question, councillors were asked to assess the impact of both introduced and hypothetical reforms on the council's role and status. In Poland, reforms aimed at increasing/decreasing number of municipalities have never been implemented on a large scale. There were also no reforms aimed at transferring powers of municipalities to higher levels of local government and those lowering the electoral age. Therefore, all above-mentioned reforms should be treated as hypothetical. 


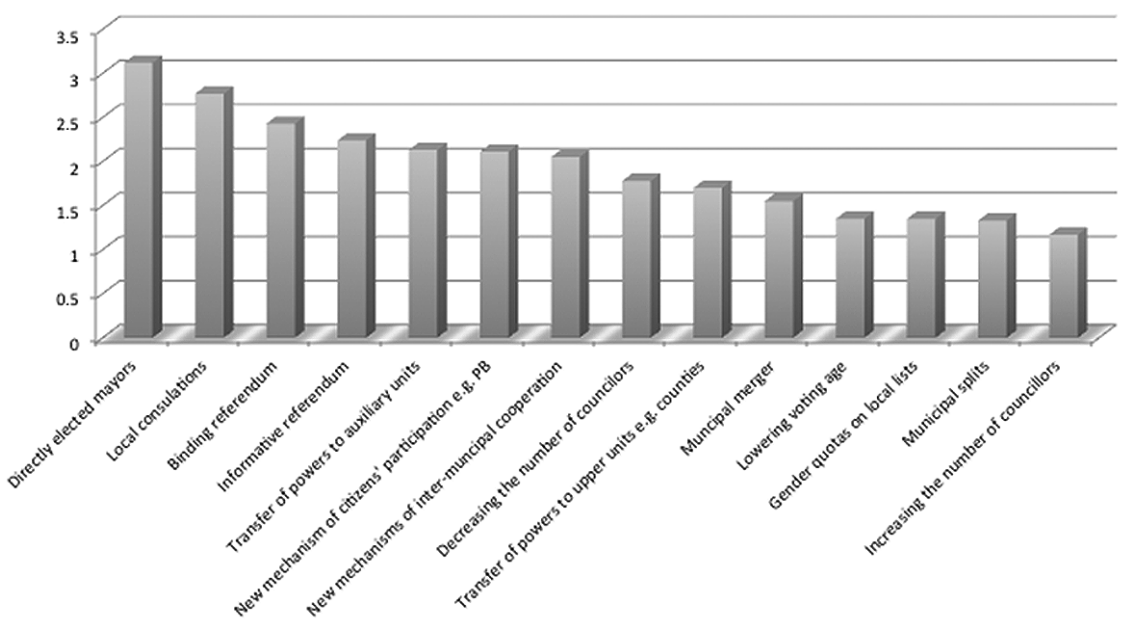

Figure 3. The impact of introduced/hypothetical local reforms on a council's role and status as perceived by councillors

Mean value: $0-4$

Source: Own studies.

One of the councillors commented on this in the following manner: “(...) now we have the politics of things already decided, all we ought to be doing is raising our hands to secure the money for some kind of project, there is no discussion whether we think this to be good or bad for our town" (Councillor 1, Zamość).

The fact that the mayor has overall control of how the budget is governed also has an influence on investments in constituencies, which is where the councillors originate from (Councillor 1, Lublin; Councillor 3, Lublin). Additionally, some councillors observe the change in political culture and the fact that councils are more and more divided that often results from the division on the ruling group and the opposition. One of them comments on it in the following way: "After recent elections, the council's role has changed for the worse. The pattern comes from the top. New councillors want only to have something on somebody; consider themselves as very important opposition. Just instead of working together for the community's welfare, they interfere and hamper the work during committees' and council's meetings" (Councillor 1, Terespol).

On the contrary, in respect to deeper citizens' involvement into decision-making process councillors do not perceive it as a threat for council's status and role. Conducted interviews showed that majority of them consider new participative framework as an important supplement to representative democracy. According to one councillor: "(...) Every way to activate and engage residents into local issues is good. The only thing you have to be careful about is to throw ideas around and then not to implement them as inhabitants can be easily discouraged. I believe that every way (of residents' activation - K.R.-M.) is good (... ) I'm not afraid that people report 
something and diminish my role (as a councillor - K.R.-M.). I would be glad because then I can only coordinate actions and have less work (...)" (Councillor 2, Bełżyce).

The other councillor adds that development of citizens' participation is a natural process that cannot be stopped: "(Citizens' engagement - K.R.-M.) is a process that cannot be stopped. You cannot imagine now mayor or councillor who comes out and says »we end up with participatory budgeting «. This is like a politician would come out and say »we finish the Family 500+«"10 (Councillor 2, Lublin).

The councillors indicate, however, the complementary nature of participative mechanisms. They underline that sometimes " $(. .$.$) more democracy means the worst$ of all (...)" (Councillor 1, Łęczna) and that "Democracy is not always a great tool as the crowd has many heads, but sometimes no reason" (Councillor 1, Lublin). In this participatory context, the council is perceived as a body that links, prioritises and assures that 'things will be done'. The interviews revealed, however, one more interesting phenomenon. There is a clear gap in terms of application of new mechanisms between rural, mixed and urban municipalities. Whereas in the first two types of local units, mechanisms of citizens' involvement are still limited, in city-municipalities they are far much developed. In some cases the situation bothers local representatives. "I have a feeling that residents have big impact. On the one hand, I really like it. On the other hand, during recent months, I have started to come to the conclusion that maybe we go somewhere too far. The demanding attitude towards PB annoys me. We created certain framework and should act within it. There are many people, who want to go beyond it, you give them an inch and they will take a mile (...)" (Councillor 3, Lublin).

\section{CONCLUSIONS AND DISCUSSION}

Based on the research results presented, one can formulate the following conclusions:

1. Polish municipal councillors perceive the council mainly as the body that represents residents' interests and controls the executive. However, important council's role is also to make decisions on local matters. In this context, councillors emphasize that council should be able to prioritize local issues and to solve the most important problems. What reflects trends visible in other Central and Eastern European local governments is a relatively little importance Polish councillors attach to representing interests of local committees and political parties they belong to. Interestingly, local representatives do not see the councils also as the body that should facilitate citizens' participation.

2. According to Polish councillors, the most important and influential actor on local arena is the mayor. Nevertheless, the council ranks just behind him. Despite this seeming little difference between the bodies, many councillors have a feeling that the council is attached to the mayor, not the other way around. What is more, the dominance

${ }^{10}$ The 'Family $500+$ ' is a subsidy programme for Polish families with children launched by the Law and Justice government in 2016. It was one of the party's flagships during their electoral campaign. 
of the mayor including his/her impact on local budget and investments influences, in some municipalities, the relation between elected representatives and residents.

3. From the councillors' perspective the most significant impact on council's role in governing process had the introduction of directly elected mayors. The 2002 reform not only changed the leadership model but also visibly reduced the council's influence on the outcomes of the governing process as such. Additionally, in many municipalities 'strong-mayor form' led to division within the council into the group supporting the executive and the one remaining in the opposition. However, at the same time, the results of the interviews indicate that majority of councillors notices the benefits of individual mayoral leadership and is in favour of the current model. Nevertheless, according to Polish councillors, the second biggest impact on council's role have had reforms connected with citizens' participation although their influence is still rather limited and clearly visible only in big, urban municipalities where participatory framework is complex. Therefore, in terms of citizens' participation there are still visible differences between small and big local units.

In her paper about the impact of NPM ideology on elected representatives in Denmark, Karen Hansen writes that "local government is - like government in general - in a state of change" [Hansen 2001: 105]. From the perspective of 26-year history of Polish local democracy this statement also sounds very true. Although local self-government in Poland, especially at municipal level, has strong status, the dynamic of change of its institution is still relatively high.

In Poland, elected councils formally constitute the foundation of local democracy. Taking into account the real-life practice, it is clear, however, that their role and status have evolved a lot since the 1990s. Presently, they definitely cannot be labelled as 'rubber-stamps'. Nevertheless, in many municipalities they seem to play second fiddle to the mayor. Therefore, one of the biggest challenges for elected representatives is to reconcile their relation with the executive and to create their own leadership. One of the possible strategies is to build stronger alliances with the residents. As one councillor indicated "(The mayor - K.R.-M.) can afford not to co-govern with the council, but cannot afford not to co-govern along with the residents" (Councillor 2, Lublin). This new perspective, however, demands that councillors do not perceive greater citizen involvement in the decision-making process as an unnecessary obstacle to proper representative democracy operation, but as an opportunity to increase their input into the process of governing.

\section{BIBLIOGRAPHY}

Bäck, H., Heinelt, H., Magnier, A. (eds.) 2006. The European Mayor. Political Leadersin the Changing Context of Local Democracy, VS Verlag für Sozialwissenschaften, Wiesbaden.

Berg, R., Rao, N. (eds.) 2005. Transforming Political Leadership in Local Government, Palgrave Macmillan, New York. 
Campbell, A., Coulson, A. 2006. Into the mainstream: Local democracy in Central and Eastern Europe, "Local Government Studies", vol. 32, no. 5, pp. 543-561.

Daemen, H. 2012. Revitalising Representative Democracy, [in:] Renewal in European Local Democracies. Puzzles, Dilemmas and Options, L. Schaap, H. Daemen (eds.), Springer VS, Wiesbaden.

Denters, B., Klok, P-J. 2012. Councillor attitudes to 'interactive' governance. Evidence from a survey in five Dutch urban municipalities, [in:] Regieren. Festschrift für Hubert Heinelt, B. Egner, M. Haus, G. Terizakis (eds.), Springer VS, Wiesbaden.

Denters, B., Rose, L. E. 2005. Local Governance in the Third Millennium: A Brave New World?, [in:] Comparing Local Governance, Trends and Developments, B. Denters, L.E. Rose (eds.), Palgrave Macmillan, Basingstoke.

Fischer, F. 2012. Participatory Governance: From Theory to Practice, [in:] The Oxford Handbook of Governance, D. Levi-Faur (ed.), Oxford University Press, Oxford.

Hansen, K. 2001. Local Councillors: Between Local 'Government' and Local 'Governance', "Public Administration", 79, pp. 105-123, doi: 10.1111/1467-9299.00248.

Heinelt, H. 2013. Councillors; Notion of Democracy, and their Role Perception and Behaviour in the Changing Context of Local Democracy, "Local Government Studies", vol. 39, no. 5, pp. 640-660.

Manin, B. 1997. The Principles of Representative Government, Cambridge University Press, Cambridge.

Nyholm, I., Haveri, A. 2009. Between Government and Governance - Local Solutions for Reconciling Representative Government and Network Governance, "Local Government Studies", vol. 35, no. 1, pp. 109-124.

Pitkin, H. 1969. Representation, Atherton Press, New York.

Radzik-Maruszak, K. 2014. The Changing Role of Councillors in Poland: Contexts and Capabilities, "Contemporary European Studies", vol. 2, pp. 5-21.

Radzik-Maruszak, K. 2016. Roles of Municipal Councils in Poland and in the Czech Republic. Factors Shaping the Roles and the Dynamic of Change, "Journal of Universal Excellence", vol. 5, no. 1, pp. 47-64.

Swianiewicz, P. 2012. Poland: Europeanization of Subnational Governments, [in:] The Oxford Handbook of Local and Regional Democracy in Europe, J. Loughlin, F. Hendriks, A. Lindström (eds.), Oxford University Press, Oxford.

Swianiewicz, P. 2014. Intra-Municipal Units in Urban Political System in Poland: Vicious Roundabout of Marginalization or Dead-end street?, "The NISPAcee Journal of Public Administration and Policy", vol. VII, no. 2, pp. 173-198.

Tuurnas, S. 2015. Learning to Co-produce? The Perspective of Public Service Professionals, "International Journal of Public Sector Management”, vol. 28, no. 7, pp. 583-598.

\section{BIOGRAPHY}

Katarzyna Radzik-Maruszak, PhD, Assistant Professor in the Department of Local Government and Politics, Faculty of Political Science, Maria Curie-Skłodowska University in Lublin, Poland. In her research and teaching she focuses mainly on public administration reforms and comparative local governance. She also maintains an interest in problems of local representative democracy, in particular the role and responsibilities of elected representatives. Dr Katarzyna Radzik-Maruszak can be contacted at: katarzyna.radzik@umcs.pl 